\title{
The Aromatic Domain of the Coronavirus Class I Viral Fusion Protein Induces Membrane Permeabilization: Putative Role during Viral Entry ${ }^{\dagger}$
}

\author{
Bruno Sainz, Jr., Joshua M. Rausch, ${ }^{\S}$ William R. Gallaher," Robert F. Garry, ${ }^{\ddagger}$ and William C. Wimley*,§ \\ Department of Microbiology and Immunology, Program in Molecular Pathogenesis and Immunity, and Department of \\ Biochemistry, Tulane University Health Sciences Center, New Orleans, Louisiana 70112, and Department of Microbiology, \\ Immunology, and Parasitology, Louisiana State University Health Sciences Center, New Orleans, Louisiana 70112
}

Received July 13, 2004; Revised Manuscript Received November 1, 2004

\begin{abstract}
Coronavirus (CoV) entry is mediated by the viral spike (S) glycoprotein, a class I viral fusion protein. During viral and target cell membrane fusion, the heptad repeat (HR) regions of the S2 subunit assume a trimer-of-hairpins structure, positioning the fusion peptide in close proximity to the C-terminal region of the ectodomain. The formation of this structure appears to drive apposition and subsequent fusion of viral and target cell membranes; however, the exact mechanism is unclear. Here, we characterize an aromatic amino acid rich region within the ectodomain of the S2 subunit that both partitions into lipid membranes and has the capacity to perturb lipid vesicle integrity. Circular dichroism analysis indicated that peptides analogous to the aromatic domains of the severe acute respiratory syndrome (SARS) - CoV, mouse hepatitis virus (MHV) and the human CoV OC43 S2 subunits, did not have a propensity for a defined secondary structure. These peptides strongly partitioned into lipid membranes and induced lipid vesicle permeabilization at peptide/lipid ratios of 1:100 in two independent leakage assays. Thus, partitioning of the peptides into the lipid interface is sufficient to disorganize membrane integrity. Our study of the S2 aromatic domain of three $\mathrm{CoVs}$ provides supportive evidence for a functional role of this region. We propose that, when aligned with the fusion peptide and transmembrane domains during membrane apposition, the aromatic domain of the CoV S protein functions to perturb the target cell membrane and provides a continuous track of hydrophobic surface, resulting in lipid-membrane fusion and subsequent viral nucleocapsid entry.
\end{abstract}

The global outbreak of severe acute respiratory syndrome (SARS) began in the fall of 2002 in the Guangdong Province of China. By July of 2003, 8098 probable cases had been reported, resulting in 774 deaths in 29 countries worldwide (1). The etiological agent of SARS was quickly identified as belonging to the family Coronaviridae (2-7), a group of large enveloped RNA viruses exhibiting a broad host range and capable of causing respiratory, hepatic, and enteric diseases (8). Because of its recent emergence, relative ease of transmission, and disease severity, it is necessary to gain a better understanding of the pathogenesis of this virus to develop antiviral drugs and vaccines for the treatment and prevention of SARS.

All viruses must bind and invade their target cells to replicate. Entry of enveloped animal viruses requires fusion between the viral membrane and a cellular membrane, either the plasma membrane or an internal membrane. Fusion is

$\dagger$ This work was supported by the National Institutes of Health (AI054626, AI054238, RR018229, and CA08921 to R.F.G. and GM60000 to W.C.W.). B.S. is a recipient of a National Research Service Award from the NIH (AIO543818).

* To whom correspondence should be addressed. Telephone: 504988-7076. Fax: 504-988-2739. E-mail: wwimley@tulane.edu.

$\doteqdot$ Department of Microbiology and Immunology, Program in Molecular Pathogenesis and Immunity, Tulane University Health Sciences Center.

$\S$ Department of Biochemistry, Tulane University Health Sciences Center.

"Louisiana State University Health Sciences Center. mediated by viral fusion proteins, of which two classes have been identified for enveloped RNA viruses. Class I fusion proteins contain (1) a fusion peptide at or near the amino terminus consisting of a stretch of $\sim 20$ hydrophobic amino acids, (2) a pair of extended $\alpha$ helices, specifically 4,3hydrophobic heptad repeats (HR), and generally, (3) a cluster of aromatic amino acids proximal to (4) a hydrophobic transmembrane (TM) anchoring domain (9-12). Gallaher and colleagues have shown that several otherwise disparate viruses, including orthomyxoviruses, paramyxoviruses, retroviruses, arenaviruses, and filoviruses, all encode class I fusion proteins, varying in length and sequence but highly similar in overall structure $(13,14)$. The class II fusion proteins of alphaviruses and flaviviruses also contain an internal fusion peptide but are comprised of three antiparallel $\beta$-sheet domains (15-17).

Coronaviruses rely solely on the membrane-bound viral spike (S) glycoprotein to bind and infect host cells. The S1 subunit of the $\mathrm{S}$ glycoprotein mediates receptor binding (18, 19), while the S2 subunit is responsible for driving viral and target cell membrane fusion (20). Recent studies indicate that the HR regions of the $\mathrm{S}$ protein of murine hepatitis virus (MHV) and SARS-CoV form a trimer-of-hairpins, a hallmark structure observed for class I viral fusion proteins of other RNA viruses. Using peptides corresponding to the two HR regions of the $\mathrm{S} 2$ subunit, Bosch et al. showed that HR1 and HR2 of the MHV S2 subunit assemble into a stable 
antiparallel oligomeric complex (21). Liu et al. demonstrated a similar association between the two HR regions of SARS$\mathrm{CoV}$ (22). Most recently, using systematic peptide mapping, Tripet et al. showed that the site of interaction between HR1 and HR2 of the SARS - CoV S2 subunit is between residues 916-950 of HR1 and residues 1151-1185 of HR2 (23). They propose that, upon receptor binding, the two HR regions of S2 assume a collapsed antiparallel 6-stranded $\alpha$-helical structure (trimer-of-hairpins) that draws the target cell and viral membranes together (23). The subsequent membrane juxtaposition is believed to result in the destabilization of both membranes, causing fusion and/or pore formation and entry of the viral nucleocapsid into the target cell $(12,24-28)$. These results and additional analyses presented herein demonstrate inherent similarities between the CoV S protein and fusion proteins of other RNA virus, such as HIV $(13,14,29)$, indicating that the CoV S protein is a class I viral fusion protein.

A trimer-of-hairpins structure is a recurring theme for class I viral fusion proteins. Trimer-of-hairpins have been identified through X-ray crystallographic methods for the filovirus Ebola (30-32), oncogenic retroviruses $(33,34)$, lentiviruses HIV and SIV (30, 35, 36), orthomyxovirus influenza (37), paramyxovirus SV5 (38), and most recently for MHV (39) and SARS - CoV (40). In each case, formation of the trimerof-hairpins brings the $\mathrm{N}$-terminal region of the viral fusion protein into close proximity to the C-terminal region of the ectodomain, postioning both the fusion peptide and TM domains at the same end of the molecule. The apposition of both the target cell and viral membranes is believed to result in membrane fusion; however, the exact mechanism is unclear but likely involves the formation of a fusion pore through which the viral nucleocapsid enters the target cell $(41-46)$. Several studies $(47-50)$ suggest that the insertion of the fusion peptide alone into the target cell membrane could potentially cause the membrane distortion necessary for fusion, because of its high propensity to partition into the membrane interface as measured by the interfacial hydrophobicity scale developed by Wimley and White (WW) (51). In addition to the fusion peptide, however, a second region consisting of aromatic amino acids proximal to the TM domain in the fusion proteins of HIV and EboV also demonstrate a high tendency to partition into the membrane interface according to the WW interfacial hydrophobicity scale (51-54). This region of aromatic amino acids, according to the trimer-of-hairpins model, would also align with the fusion peptide and TM domain during apposition of the target cell and viral membranes and thus could add to the overall hydrophobicity of the environment and contribute to the distortion of the lipid membranes necessary for fusion. Using synthetic peptides analogous to the aromatic domains of HIV-1 gp41 and EboV glycoprotein 2 (GP2), Nieva and colleagues have shown that these aromatic regions partition into and perturb the integrity of lipid vesicles $(10,55,56)$. Not surprisingly, proximal to the TM domain of the CoV S protein, there is a similar region enriched in aromatic amino acids, which is extraordinarily conserved throughout the Coronaviridae and lies in an identical location to the aromatic domains of HIV (Figures 1 and 2) and EboV (Figure 2).

Previous studies identifying and characterizing functional domains of class I viral fusion proteins of Influenza virus
(9, 47, 57), $\operatorname{HIV}(10,48,49,56,58)$, and $\operatorname{EboV}(50,55,59)$ have done so in part using peptides analogous to specific regions of these proteins. Because synthetic peptides have been shown to be good models to study membrane-associated structures and processes functioning in viral fusion $(21-23$, $26,38,60-64)$, we investigated the biochemical and functional characteristics of peptides analogous to the aromatic domain of SARS-CoV, MHV, and the human CoV OC43. We show that this conserved and highly aromatic region of the CoV S2 subunit strongly partitions into the membranes of lipid vesicles with a preference for vesicles containing anionic lipids, such as phosphatidyl-inositol or phosphatidyl-glycerol. Further, we demonstrate that this region alone perturbs membrane integrity and causes leakage of vesicle contents in two independent leakage assays. Our study of the S2 aromatic domain of three $\mathrm{CoV}$ is consistent with previous findings for $\mathrm{HIV}$ and $\operatorname{EboV}(10,55)$ and provides putative evidence for a functional role of this aromatic domain in viral fusion and entry. In addition, these studies provide additional evidence to support the hypothesis set forth by Bosch et al. that the CoV S2 subunit is a class I viral fusion protein.

\section{EXPERIMENTAL PROCEDURES}

Peptide Synthesis. The $\mathrm{CoV}$ aromatic $\left(\mathrm{SARS}_{\text {aro }}, \mathrm{MHV}_{\text {aro }}\right.$, and $\mathrm{OC}_{4} 3_{\text {aro }}$ ) and SARS $-\mathrm{CoV}$ scrambled $\left(\mathrm{SARS}_{\mathrm{scr}}\right)$ peptides were synthesized by solid-phase methodology using a semiautomated peptide synthesizer and conventional $N-\alpha$ 9-fluorenylmethyloxycarbonyl (Fmoc) chemistry by Genemed Synthesis, Inc. (San Francisco, CA). Peptides were purified by reversed-phase high-performance liquid chromatography, and their purity was confirmed by amino acid analysis and electrospray mass spectrometry. Peptide stock solutions were prepared in dimethyl sulfoxide (DMSO) ${ }^{1}$ (spectroscopy grade), and concentrations were determined spectroscopically (SmartSpec 3000, BioRad, Hercules, CA).

Large Unilamellar Vesicle (LUV) Preparation. LUVs consisting of 1-palmitoyl-2-oleoyl-sn-glycero-3-phosphatidylcholine (POPC) with 1-palmitoyl-2-oleoyl-sn-glycero-3phosphatidylglycerol (POPG), L- $\alpha$-phosphatidylinositol from bovine liver (PI) (Avanti Polar Lipids, Birmingham, AL), and/or cholesterol (CHOL) (Sigma, St. Louis, MI) were prepared according to the extrusion method of Nayar et al. $(65,66)$. Briefly, lipids were dried from chloroform solution with a nitrogen gas stream and high vacuum overnight. Lipid vesicles used in peptide-binding assays and circular dichroism (CD) experiments were resuspended in $10 \mathrm{mM}$ potassium phosphate buffer at $\mathrm{pH} 7.0$ to bring the concentration to 100 $\mathrm{mM}$ total lipid. Samples were subjected to repeated freeze and thaw for 15 cycles followed by extrusion through 0.1 $\mu \mathrm{m}$ polycarbonate membranes in a Lipex Biomembranes extruder (Lipex Biomembranes, Vancouver, BC). To prepare terbium(III) chloride hexahydrate $\left(\mathrm{Tb}^{3+}\right)$ LUVs, lipids were resuspended to $100 \mathrm{mM}$ concentration in $50 \mathrm{mM} \mathrm{Tb}^{3+}, 100$

\footnotetext{
${ }^{1}$ Abbreviations: ANTS, disodium 8-aminonaphthalene-1,3,6-trisulfonic acid; DMSO, dimethyl sulfoxide; DPA, 2,6-pyridine dicarboxylic acid; DPX, $p$-xylene-bispyridinium bromide; PI, L- $\alpha$-phosphatidylinositol from bovine liver; POPC, 1-palmitoyl-2-oleoyl-sn-glycero-3phosphatidylcholine; POPG, 1-palmitoyl-2-oleoyl-sn-glycero-3-phosphatidylglycerol; $\mathrm{Tb}^{3+}$, terbium(III) chloride hexahydrate; TES, $N$-tris(hydroxymethyl)methyl-2-aminoethane sulfonic acid.
} 


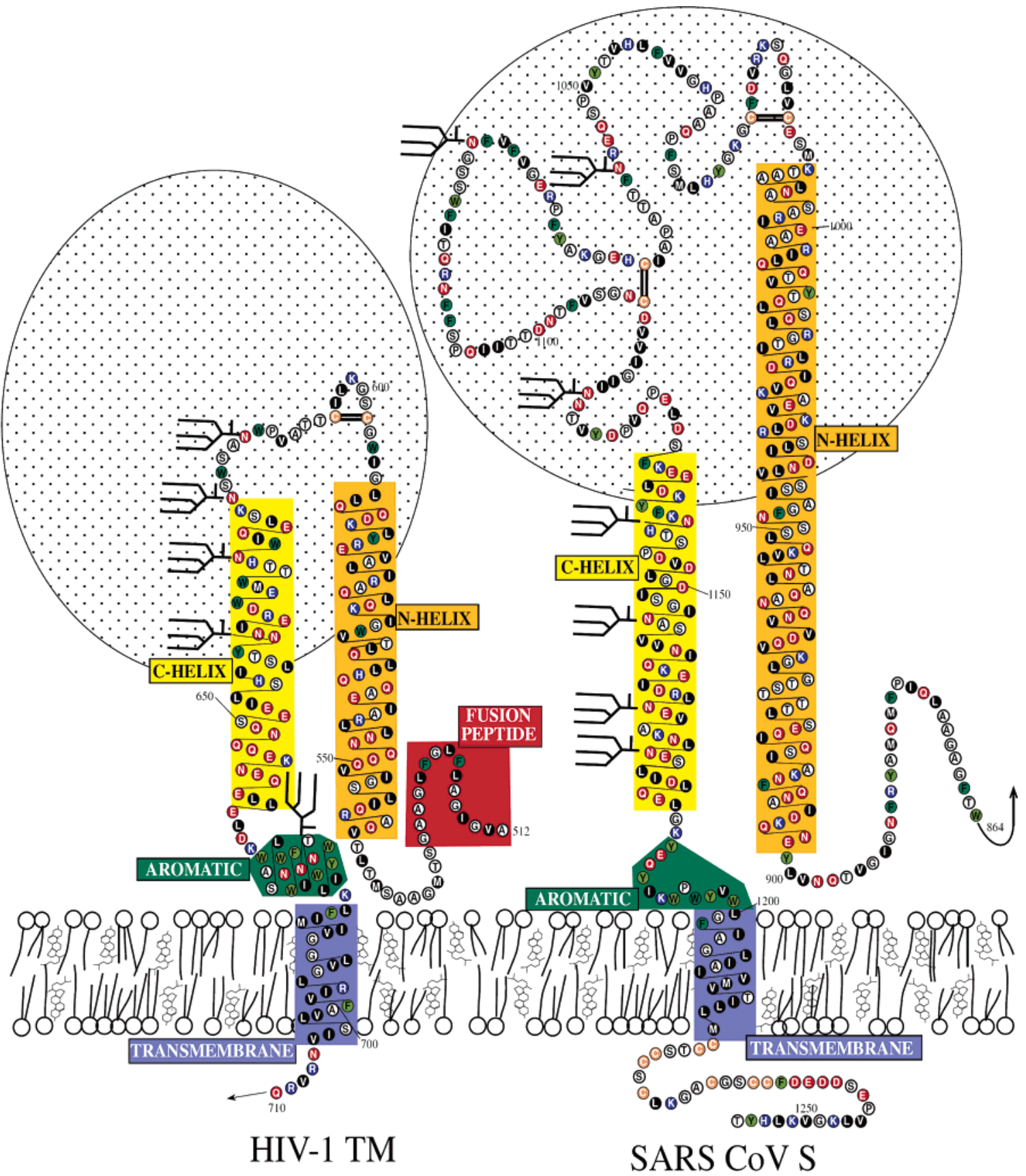

FIGURE 1: Schematic comparison of the HIV-1 TM with the SARS-CoV S protein. (Left) Updated model of HIV-1 TM from Gallaher et al. and Garry et al. $(13,17)$. (Right) Hypothetical model of SARS-CoV S (S2 subunit) showing motifs shared with HIV-1 TM. The amino terminus of the S2 portion is not depicted. The two HR $\alpha$-helical regions, $\mathrm{N}$ helix (HR1, orange) and $\mathrm{C}$ helix (HR2, yellow), are depicted at amino acid residues 902-1011 and 1131-1185, respectively. This is consistent with the HR predictions of both Tripet et al. (23) and Liu et al. (22). An interhelical domain of approximately 130 amino acids is depicted between the $\mathrm{N}$ and $\mathrm{C}$ helices. This region is extremely similar to the interhelical region for retrovirus TM proteins and EboV GP2 and has therefore been modeled as a similar disulfide-stabilized apex. Just prior to the TM anchor (indigo) of S2, there is a region enriched in aromatic amino acids. This region, termed the aromatic domain (green), is highly conserved throughout the Coronaviridae and lies in an identical location to the aromatic domains of HIV and EboV. The S1 subunit, which includes the receptor-binding domain, is depicted schematically as a large ellipse, corresponding to the characteristic large globular headgroups seen in electron micrographs of $\mathrm{CoV}$.

$\mathrm{mM}$ sodium citrate, and $10 \mathrm{mM} N$-tris(hydroxymethyl)methyl-2-aminoethane sulfonic acid (TES) at pH 7.2. Gel filtration on Sephadex G-200 was used to remove unencapsulated terbium in a buffer of $10 \mathrm{mM}$ TES and $325 \mathrm{mM}$ $\mathrm{NaCl}$ (67). Disodium 8-aminonaphthalene-1,3,6-trisulfonic acid (ANTS)/p-xylene-bispyridinium bromide (DPX) LUVs were prepared in an analogous manner using a resuspension buffer of $25 \mathrm{mM}$ ANTS and $5 \mathrm{mM}$ DPX (Molecular Probes, Eugene, OR) in $10 \mathrm{mM}$ potassium phosphate at $\mathrm{pH} 7.0$ (68). LUVs were eluted from a Sephadex G-200 gel column using
$10 \mathrm{mM}$ potassium phosphate at $\mathrm{pH}$ 7.0. Final lipid concentrations were determined by phosphate analysis $(69,70)$.

Peptide-Binding Assay. Partitioning of peptides into lipid bilayer was monitored by the fluorescence enhancement of tryptophan (71). Fluorescence was recorded at excitation and emission wavelengths of 280 and $340 \mathrm{~nm}$, respectively, and $8 \mathrm{~nm}$ bandwidths using an SML Aminco 8100 spectrofluorometer (Rochester, NY). Quartz cuvettes were used with excitation and emission path lengths of 4 and $10 \mathrm{~mm}$. The measurements reported here were carried out in $10 \mathrm{mM}$ 

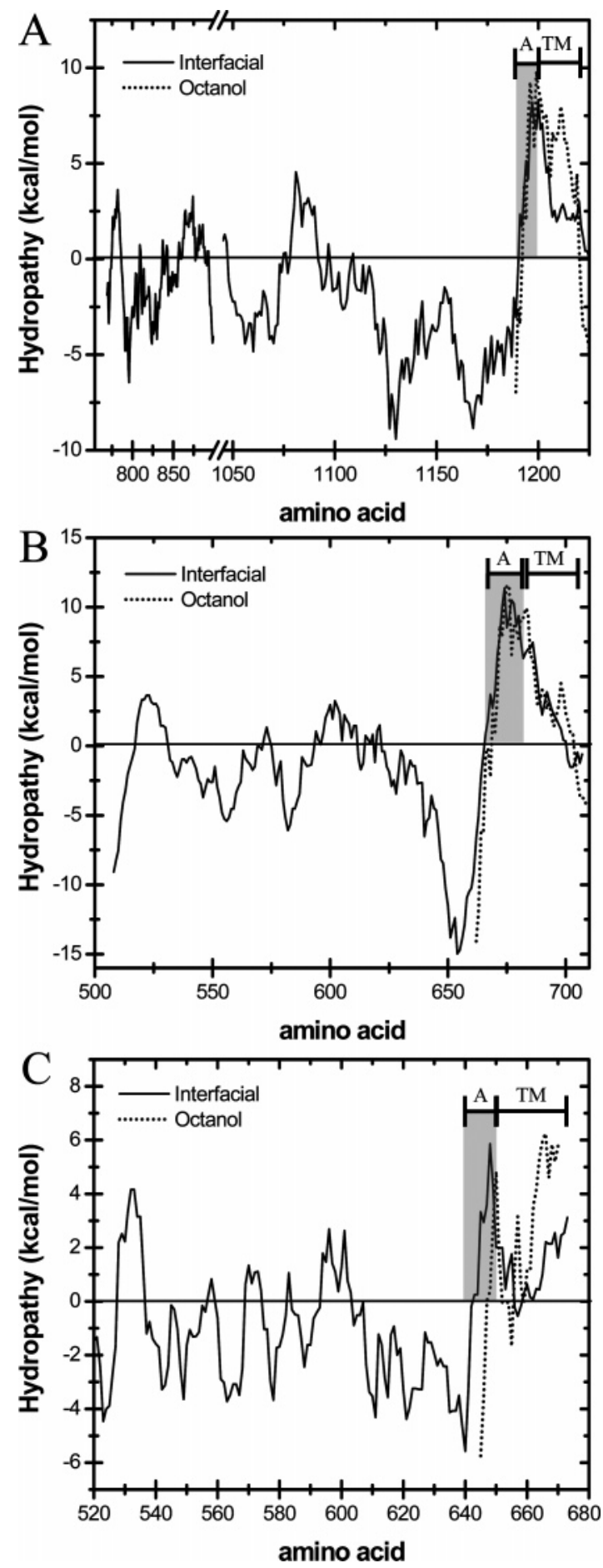

FIGURE 2: Hydropathy plots corresponding to sequences of SARSCoV S2, HIV-1 gp41, and EboV GP2. WW interfacial hydrophobicity plots (-) (51) and WW octanol hydrophobicity plots (- - (73) were generated for individual residues of (A) the SARS - CoV strain Urbani S2 subunit (amino acids 775-1225), (B) HIV-1 strain HXB2 gp41 (amino acids 502-710), and (C) EboV strain Zaire GP2 (amino acids 520-676). Mean values for a window of 13 residues are plotted. Areas shaded in gray represent aromatic domains of the represented class I viral fusion proteins. A = aromatic domain, and $\mathrm{TM}=$ transmembrane domain.

potassium phosphate at $\mathrm{pH}$ 7.0. In other buffer systems, the coefficients are very similar, indicating that partitioning is not sensitive to the exact buffer conditions or ionic strength. Peptides were added from DMSO stock solutions to $250 \mu \mathrm{L}$ of buffer and mixed by inversion. Likewise, LUVs were titrated to a final lipid concentration of $1 \mathrm{mM}$ and mixed by inversion. Intensity values $(I)$ were adjusted for lipid scattering and normalized to the peptide in buffer $\left(I_{0}\right)$. Partitioning coefficients were obtained using eq 1 where $K_{x}$ is a mole

$$
\begin{array}{r}
I / I_{0}=1+\left(\left(K_{x} \times[\mathrm{L}]\right) /\left([W]+\left(K_{x} \times[L]\right)\right)\right) \times \\
\left(\left(I_{\max } / I_{0}\right)-1\right)
\end{array}
$$

fraction partition coefficient that represents the amount of peptide in bilayers as a fraction of the total peptide present in the system, $I_{\max }$ is a variable value for the fluorescence enhancement at complete partitioning determined by fitting the equation to the experimental data, $[L]$ is the concentration of the lipid, and $[W]$ is the concentration of water $(55.3 \mathrm{M})$.

$\mathrm{Tb}^{3+} / 2,6-$ Pyridine Dicarboxylic Acid (DPA) Microwell Plate Assay. For the microwell plate assay, a $200 \mu \mathrm{L}$ aliquot of vesicle solution containing $500 \mu \mathrm{M} \mathrm{Tb}^{3+}$ LUVs in $10 \mathrm{mM}$ TES, $50 \mu \mathrm{M}$ DPA, and $325 \mathrm{mM} \mathrm{NaCl}$ at $\mathrm{pH} 7.2$ was pipetted into each well of a plastic $8 \times 12$ format plate (67). Peptides in DMSO were added to each well at peptide/lipid (P/L) molar ratios of 1:500, 1:250, 1:100, and 1:50; well contents were thoroughly mixed, and plates were allowed to incubate at room temperature for $2 \mathrm{~h}$. In addition to peptide-treated wells, DMSO-treated and Triton X-100-treated (Sigma) wells served as negative and positive controls, respectively. After incubation for $2 \mathrm{~h}, \mathrm{~Tb}^{3+} / \mathrm{DPA}$ fluorescence was visualized under horizontally mounted short-wave $(254 \mathrm{~nm})$ ultraviolet (UV) light sources in a darkroom (67). Plates were photographed, and images were recorded on a Nikon Coolpix 995 using a $4 \mathrm{~s}$ exposure time with 100 speed, 2.6 aperture, and a $540 \mathrm{~nm}$ band-pass optical filter between the sample and lens. For each experimental plate, the $\mathrm{Tb}^{3+} / \mathrm{DPA}$ fluorescence for the peptide-treated wells was compared to that of wells containing the same amount of untreated vesicles and to wells containing vesicles that had been lysed with the detergent Triton X-100. Color adjustment and contrasting were normalized to negative controls using Adobe Photoshop.

ANTS/DPX Leakage Assay. ANTS and DPX were entrapped in LUVs at concentrations of 25 and $5 \mathrm{mM}$, respectively. Peptides were added to $500 \mu \mathrm{M}$ lipid solution in $10 \mathrm{mM}$ potassium phosphate at $\mathrm{pH} 7.2$ and $\mathrm{P} / \mathrm{L}$ molar ratios of 1:500, 1:250, 1:100, and 1:50. Although most ANTS/DPX leakage occurred in the first several hours after peptide addition, samples were shaken overnight at room temperature to allow the leakage to go to completion. Fluorescence was recorded at excitation and emission wavelengths of 350 and $510 \mathrm{~nm}$, respectively, and $8 \mathrm{~nm}$ bandwidths using an SML Aminco 8100 spectrofluorometer. Quartz cuvettes were used with excitation and emission path lengths of 4 and $10 \mathrm{~mm}$, respectively. The percent change in fluorescence was defined by eq 2 where $F_{\max }$ is obtained

$$
\% \text { fluorescence }=\left(\left(F-F_{0}\right) /\left(F_{\max }-F_{0}\right)\right) \times 100 \%
$$

by adding $25 \mu \mathrm{L}$ of $5 \%$ Triton $\mathrm{X}-100$ and $F_{0}$ is equivalent to DMSO controls. Percent leakage was calculated from the fraction released $\left(f_{\text {out }}\right)$, where $f_{\text {out }}$ was determined using curve fitting by numerically solving eq 3 where $f_{\text {out }}$ is the fractional

$\%$ fluorescence $=100 \times\left(f_{\text {out }}+\left(1-f_{\text {out }}\right) \times\right.$

$\left.I\left([\mathrm{DPX}]_{\mathrm{in}}\right)\right)$ 
leakage from the vesicles and $I\left([\mathrm{DPX}]_{\text {in }}\right)$ is the fluorescence intensity of the fraction of ANTS that remains entrapped. The entrapped ANTS is quenched by the DPX that remains entrapped, $[\mathrm{DPX}]_{\mathrm{in}}$. For each point, $[\mathrm{DPX}]_{\text {in }}$ is calculated by $\left(1-f_{\text {out }}\right) \times[\mathrm{DPX}]_{0}$, where $[\mathrm{DPX}]_{0}$ is the initial concentration of DPX.

CD Spectroscopy. CD spectra were recorded on a Jasco J-810 spectropolarimeter (Jasco Inc., Easton, MD), using a $1 \mathrm{~mm}$ path length, $1 \mathrm{~nm}$ bandwidth, $16 \mathrm{~s}$ response time, and a scan speed of $10 \mathrm{~nm} / \mathrm{min}$. All CD runs were performed at room temperature with the peptide dissolved in $10 \mathrm{mM}$ potassium phosphate buffer at $\mathrm{pH}$ 7.0. LUVs were added at a lipid concentration of $1 \mathrm{mM}$ from a stock in $10 \mathrm{mM}$ potassium phosphate buffer at $\mathrm{pH} 7.0$ and allowed to incubate for $\sim 30 \mathrm{~min}$. Three successive scans between 190 and 250 $\mathrm{nm}$ were collected, and the CD data are expressed as the mean residue ellipticity, derived from the formula $\Theta=(\mathrm{deg}$ $\left.\times \mathrm{cm}^{2}\right) / \mathrm{dmol}$.

Proteomics Computational Methods. Methods to derive general models of surface glycoproteins have been described previously (13). Domains with significant propensity to form TM helices were identified with TMpred (ExPASy, Swiss Institute of Bioinformatics) and Membrane Protein eXplorer (MPeX, Stephen White laboratory, http:// blanco.biomol.uci.edu/mpex). TMpred is based on a statistical analysis of TMbase, a database of naturally occurring TM glycoproteins (72), while MPeX detection of membranespanning sequences is based on experimentally determined hydrophobicity scales $(51,54)$. Sequences with a propensity to partition into the lipid bilayer were also identified with MPeX using interfacial settings.

\section{RESULTS}

Interfacial Hydrophobicity Analysis and Peptide Sequences. WW hydrophobicity scales were used to identify regions of the $\mathrm{S} 2$ subunit of the CoV S protein with high propensity to partition into lipid membranes. These scales are based on the free energies of transfer $\Delta G(\mathrm{kcal} / \mathrm{mol})$ of amino acid sequences from water into bilayer interfaces and into $n$-octanol, taking into consideration the contribution from the peptide bond (51). The octanol scale is used as a predictor of TM domains (73), while the interfacial scale predicts interfacial binding (51). Because of the salient similarities between the S2 subunit and the class I fusion proteins of other RNA viruses such as HIV-1 (Figure 1), we compared the hydrophobicity plots of the SARS-CoV S2 subunit to that of the HIV-1 gp41 and EboV GP2 (Figure 2).

When the average interfacial hydrophobicity was plotted for the fusion proteins of these three viruses, similar regions with high propensity for membrane partitioning were detected (Figure 2). At the N-terminal region of all three fusion proteins, a region of high interfacial hydrophobicity was detected. For HIV-1 and EboV, this region corresponds to the viral fusion peptide (parts B and C of Figure 2). Although no putative fusion peptide has been determined for the SARS-CoV fusion protein, a stretch of 19 hydrophobic amino acids comprised of residues 770 MWKTPTLKYFGGFNFSQIL 788 with an average interfacial hydrophobicity score of $3.07 \mathrm{kcal} / \mathrm{mol}$ was detected at the $\mathrm{N}$-terminal region of S2 (Figure 2A). The location of this region is 9 amino acids downstream of the minimum furin cleavage site
Table 1: Amino Acid Sequences and WW Hydrophobicity Scores of $\mathrm{CoV}$ Aromatic Peptides

\begin{tabular}{|c|c|c|c|c|}
\hline peptide & amino acid sequence ${ }^{a}$ & $\begin{array}{c}\text { net } \\
\text { charge }\end{array}$ & $\begin{array}{c}\text { position } \\
\text { within S2 }\end{array}$ & $\begin{array}{c}\mathrm{WWIH}^{b} \\
(\mathrm{kcal} / \mathrm{mol})\end{array}$ \\
\hline $\mathrm{SARS}_{\text {aro }}$ & KYEQYIKWPWYVW & +1 & $1187-1199$ & 3.58 \\
\hline $\mathrm{MHV}_{\text {aro }}$ & $\overline{\mathbf{T} Y E \overline{\mathbf{M}} Y \overline{\mathbf{V}} K W P W Y V W}$ & 0 & $1264-1276$ & 4.86 \\
\hline OC $43_{\text {aro }}$ & 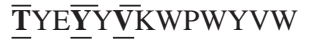 & 0 & $1289-1301$ & 5.57 \\
\hline SARS $_{\mathrm{scr}}$ & $\overline{\mathrm{Y}} \mathrm{EWK} \overline{\mathrm{WI}} \mathrm{YWYPVKQ}{ }^{c}$ & +1 & $1187-1199$ & 3.58 \\
\hline
\end{tabular}

${ }^{a}$ The SARS aromatic $\left(\mathrm{SARS}_{\mathrm{aro}}\right), \mathrm{MHV}$ aromatic $\left(\mathrm{MHV}_{\mathrm{aro}}\right)$, and OC43 aromatic (OC43 3 aro) peptides were synthesized based on their amino acid sequence determined from GenBank accession number AY278741 (SARS-CoV strain Urbani), AY497331 (MHV strain A59), and NP_937950 (human CoV OC43), respectively. Amino acid differences among the three $\mathrm{CoV}$ aromatic peptides are shown in bold and underlined text. ${ }^{b}$ Hydrophobicity scores were determined according to the Wimley and White interfacial hydrophobicity (WWIH) scale using a window of 13 residues. ${ }^{c}$ The SARS aro $_{\text {an }}$ sequence was arbitrarily scrambled to generate the peptide $\mathrm{SARS}_{\text {scr }}$.

(residues 758-761) and almost coincident with that of the HIV-1 fusion peptide; therefore, it should be considered as a possible fusion domain of the SARS-CoV S protein.

A second region of high hydrophobicity was detected at the C-terminal end of the fusion proteins, correlating to the putative TM domain of the SARS-CoV S2 (residues 11901225 of Figure 2A) and the experimentally determined TM anchors of HIV-1 gp41 and EboV GP2 (residues 665-700 of Figure 2B and residues 644-672 of Figure 2C, respectively). Nieva and colleagues have shown that, for HIV-1 and EboV, this large region of high interfacial hydrophobicity is segmented into two independent domains: one aromatic amino acid rich segment at the C-terminal portion of this domain and an adjacent segment comprising the TM anchor of the fusion protein $(10,55,56)$. The separation of this large region into two distinct domains is consistent with the observation that the $\mathrm{C}$-terminal hydrophobic domains of these viral fusion proteins are considerably longer (35-40 amino acids) than the $\sim 20$ amino acids required for a single $\alpha$ helix to span a membrane. Likewise, WW interfacial and octanol hydrophobicity plots of the C-terminal end of the SARSCoV S2 subunit shows a pattern similar to that of the HIV-1 gp41 and EboV GP2 (part A versus parts B and C of Figure 2). A 12 amino acid region rich in aromatic amino acids, with an average WW interfacial hydrophobicity score of 3.58 $\mathrm{kcal} / \mathrm{mol}$, is present. This region is proximal to a predicted TM domain (Figure 2A), which was identified using the WW octanol hydrophobicity scale that allows for the identification of TM helices of membrane proteins with very high accuracy (73). On the basis of these observations, it is unlikely that the aromatic domain is part of the TM anchor as previously predicted by Rota et al. (6), rather, as described for the aromatic domains of HIV-1 and $\mathrm{EboV}(10,55,56,58)$, this region is most likely an independent domain proximal to the TM anchor of the S2 subunit.

Sequence analysis of the S2 subunit of MHV and the human CoV OC43 showed coinciding interfacial hydrophobicity plots to that of the SARS-CoV S2 subunit (data not shown). In addition, the presence of a highly conserved aromatic domain, differing in only 3 amino acids to the SARS aromatic domain, was identified (Table 1). Interfacial hydrophobicity scores of $3.58,4.86$, and $5.57 \mathrm{kcal} / \mathrm{mol}$ were predicted for the aromatic domains of SARS-CoV, MHV, and OC43, respectively. On the basis of the these analyses, 


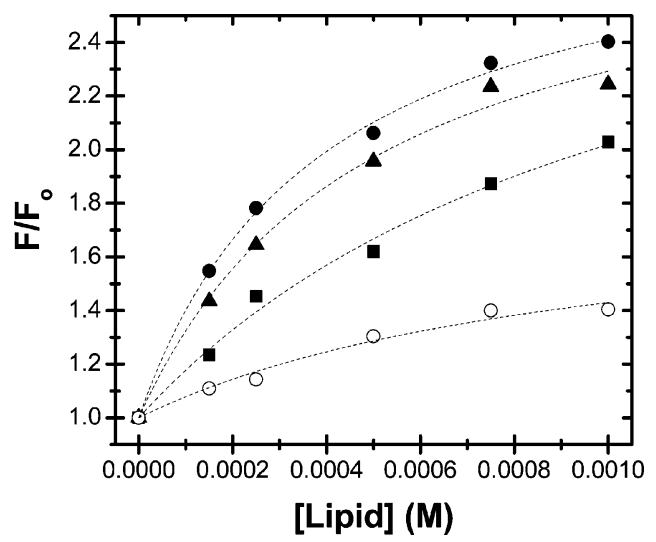

FIGURE 3: SARS aro peptide partitions into membranes of LUVs. Change in tryptophan fluorescence of $\mathrm{SARS}_{\text {aro }}$ peptide as a function of increasing concentrations of LUVs composed of ( $\mathbf{\square})$ POPC, $(\mathbf{)}$ POPC/PI (9:1), (ム) POPC/POPG (9:1), or (O) POPC/PI/CHOL (6.5: 1:2.5). LUVs were titrated at concentrations of 100, 250, 500, 750, and $1000 \mu \mathrm{M}$ lipid with $2.5 \mu \mathrm{M}$ peptide. Tryptophan fluorescence values at each lipid titration $(F)$ were normalized to tryptophan fluorescence values in $10 \mathrm{mM}$ potassium phosphate buffer alone $\left(F_{0}\right)$.

peptides of 13 amino acids in length were synthesized and used throughout this study to determine the functional importance of this region within the CoV S2 subunit (Table $1)$.

CoV Aromatic Domains Interact with Lipid Membranes. On the basis of the interfacial hydrophobicity scores of the $\mathrm{CoV}$ aromatic peptides, we believed that they could partition into membranes. We first assessed the ability of the $\mathrm{CoV}$ aromatic peptides to interact with membranes of LUVs composed of different lipid compositions. LUVs composed of POPC with PI, POPG, and/or CHOL were used as targets in partitioning experiments with the $\mathrm{CoV}$ aromatic peptides. The degree to which a peptide partitions into a lipid vesicle can be determined fluorometrically by observing the change in tryptophan fluorescence $(F)$ as a function of the increasing lipid concentration. The fluorescence of tryptophan increases in a low-polarity environment such as the lipid membrane interface. Figure 3 shows the normalized tryptophan fluorescence $\left(F / F_{0}\right)$ for the $\mathrm{SARS}_{\text {aro }}$ peptide as a function of the increasing lipid concentration of different LUVs. SARS fluorescence exponentially increased as a direct function of increasing lipid concentrations.

The partition coefficients derived from tryptophan fluorescence curves for each $\mathrm{CoV}$ peptide are summarized in Table 2. All four $\mathrm{CoV}$ peptides partitioned into lipid membranes, consistent with their hydrophobicity. The degree of partitioning for all four peptides was similar, and the presence of anionic lipids (i.e., PI or POPG) enhanced peptide partitioning. The addition of $\mathrm{CHOL}$, a natural component of mammalian membranes, decreased peptide partitioning, most notably with POPC/CHOL LUVs. This effect, however, could be partially reversed by the addition of small amounts of anionic lipids to the vesicles (Table 2), suggesting an intrinsic role for anionic lipids as part of the membrane composition.

All of the structural and functional experiments described below were carried out at lipid concentrations between 0.5 and $1 \mathrm{mM}$ lipid. The partition coefficient measurements (Table 2) were carried out at slightly lower peptide concentrations than most of the other experiments. Thus, the measured partition coefficients represent a minimum possible value because peptide self-association at higher concentrations can increase partition coefficients. Partitioning cannot be lower than that measured at an equal or lower peptide concentration. Because of this, the minimum fraction of peptide bound can be calculated from the data in Figure 3 and Table 2 by fraction bound $=\left(K_{x} \times[L]\right) /\left(K_{x} \times[L]+\right.$ $[W])$, where $[L]$ is the lipid concentration and $[W]$ is the concentration of pure water $(55.3 \mathrm{M})$. For most of the experiments in this work, the minimum fractional binding is between 30 and $90 \%$. Fractional binding to $\mathrm{CHOL}$ containing POPC was not strong enough to be accurately measured and therefore was less than $20 \%$. For clarity, we report total system composition when giving $\mathrm{P} / \mathrm{L}$ ratios. The reader should recognize that the actual $\mathrm{P} / \mathrm{L}$ ratio in the membranes will always be lower, especially for $\mathrm{CHOL}$ containing bilayers.

$\mathrm{Tb}^{3+} / \mathrm{DPA}$ Microwell Assay. To test the potential of the $\mathrm{CoV}$ aromatic peptides to perturb membrane integrity, a highthroughput leakage assay was used. The $\mathrm{Tb}^{3+} / \mathrm{DPA}$ microwell assay is a stringent, sensitive visual screening assay developed to rapidly identify peptides capable of permeabilizing lipid membranes (67). The detectability is based on the strong fluorescence emission of the lanthanide metal $\mathrm{Tb}^{3+}$ when it interacts with the aromatic chelator DPA. In this binary system, $\mathrm{Tb}^{3+}$ is entrapped in lipid vesicles, while DPA is present on the outside. Membrane permeabilization is required for the entrapped $\mathrm{Tb}^{3+}$ to interact with DPA, resulting in fluorescence emission. In the experimental assay, $\mathrm{CoV}$ aromatic peptides were incubated with $\mathrm{Tb}^{3+}$ LUVs (500 $\mu \mathrm{M}$ lipid) at $\mathrm{P} / \mathrm{L}$ molar ratios of $1: 100$ and 1:50. After incubation for $2 \mathrm{~h}$ at room temperature, the extent of $\mathrm{Tb}^{3+}$ leakage from lipid vesicles was visually determined by the detection of a bright green fluorescence upon irradiation with UV light. An example plate is shown in Figure 4 in which the SARS aro (rows 1 and 2) and SARS $_{\text {scr }}$ (rows 3 and 4) peptides were tested for their potential to permeabilize LUVs composed of POPC, POPC/PI (9:1), or POPC/POPG (9:1). The $\mathrm{SARS}_{\text {aro }}$ peptide at $\mathrm{P} / \mathrm{L}$ ratios of $1: 100$ and $1: 50$ permeabilized all three LUVs tested, with the greatest degree of fluorescence detected in wells with POPC or POPC/PI (9:1) LUVs. The extent of leakage induced by $\mathrm{SARS}_{\text {aro }}$ was less than the observed leakage in the detergent-solubilized wells (row 6 of Figure 4). However, we have found that the visual $\mathrm{Tb}^{3+} / \mathrm{DPA}$ assay is often more stringent than typical fluorometric assays of membrane permeabilization. Thus, any visible response, such as that observed in Figure 4 is taken to be a positive result. In contrast, the $\mathrm{SARS}_{\text {scr }}$ peptide did not induce leakage of any of the three LUVs tested, as detectable by this assay. Comparable results were achieved with the $\mathrm{MHV}_{\text {aro }}$ and $\mathrm{OC} 43_{\text {aro }}$ peptides at $\mathrm{P} / \mathrm{L}$ ratios of $1: 100$ and 1:50, with OC43 aro exhibiting slightly lower levels of leakage (data not shown).

ANTS/DPX Leakage Assay. We used the ANTS/DPX leakage assay, as described in the Experimental Procedures, as a means of quantitating the membrane permeabilization capacity of the $\mathrm{CoV}$ aromatic peptides. The ability of the $\mathrm{CoV}$ aromatic peptides (Figure 5) to release the encapsulated fluorescent probe ANTS from LUVs was examined at P/L ratios of 1:500, 1:250,1:100, and 1:50. Figure 5 illustrates the extent of leakage observed for all four peptides and the effect of different lipid compositions on membrane perme- 
Table 2: Partition Coefficients of CoV Aromatic Peptides

\begin{tabular}{|c|c|c|c|c|}
\hline \multirow[b]{2}{*}{ LUV compositions $^{b}$} & \multicolumn{4}{|c|}{ partition coefficients $\left(\times 10^{3}\right)^{a}$} \\
\hline & SARS $_{\text {aro }}$ & $\mathrm{MHV}_{\text {aro }}$ & OC43 aro & SARS $_{\text {scr }}$ \\
\hline POPC & $49 \pm 13$ & $101 \pm 13$ & $52 \pm 14$ & $47 \pm 11$ \\
\hline POPC/PI (9:1) & $112 \pm 18$ & $289 \pm 27$ & $104 \pm 17$ & $82 \pm 18$ \\
\hline POPC/POPG (9:1) & $142 \pm 13$ & $367 \pm 48$ & $21 \pm 9$ & $205 \pm 15$ \\
\hline POPC/CHOL $(7.5: 2.5)$ & $<20$ & $<20$ & $<20$ & $<20$ \\
\hline POPC/PI/CHOL (6.5:1:2.5) & $80 \pm 8$ & $273 \pm 36$ & $75 \pm 44$ & $89 \pm 9$ \\
\hline POPC/POPG/CHOL $(6.5: 1: 2.5)$ & $56 \pm 22$ & $115 \pm 9$ & $26 \pm 26$ & $49 \pm 11$ \\
\hline
\end{tabular}

${ }^{a}$ Partition coefficients based on spectroscopic measurements of the change in tryptophan fluorescence as a function of increasing lipid titrations Tryptophan intensity values $(I)$ were fitted to eq 1 and the resulting partition coefficients are presented as the means \pm standards errors $(n=5$ per group). ${ }^{b}$ Lipid was titrated $(100 \mu \mathrm{M}-1000 \mu \mathrm{M})$ with $2.5 \mu \mathrm{M}$ peptide in a volume of $250 \mu \mathrm{L}$.

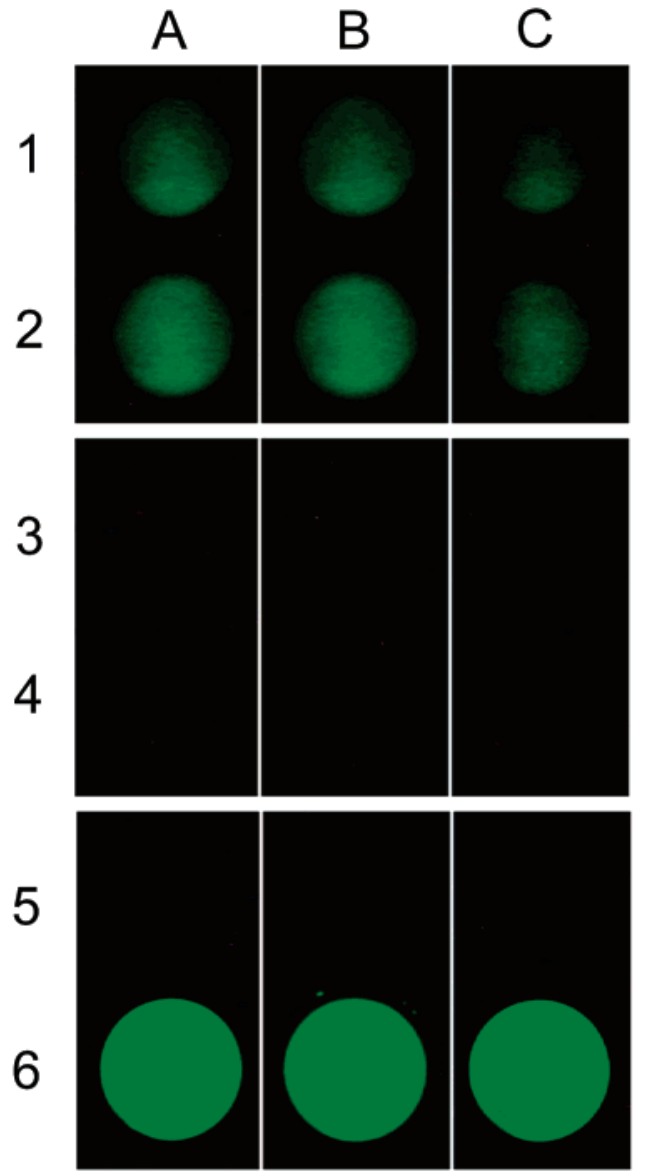

FIGURE 4: SARS aro peptide induces leakage of LUVs. Each well contained $250 \mu \mathrm{L}$ of $50 \mu \mathrm{M}$ DPA and $500 \mu \mathrm{M} \mathrm{Tb}^{3+}$-encapsulated LUVs composed of (A) POPC, (B) POPC/PI (9:1), or (C) POPC/ POPG (9:1). Wells were treated with SARS ${ }_{\text {aro }}$ peptide at P/L molar ratios of $1: 100$ or 1:50 (1 and 2), $\mathrm{SARS}_{\text {scr }}$ peptide at $\mathrm{P} / \mathrm{L}$ molar ratios of $1: 100$ or $1: 50$ (3 and 4), $20 \mu \mathrm{L}$ of DMSO (5), or $20 \mu \mathrm{L}$ of Triton X-100 (6). Plates were incubated for $2 \mathrm{~h}$ at room temperature, and membrane permeabilization was determined by visual detection of $\mathrm{Tb}^{3+} / \mathrm{DPA}$ fluorescence.

abilization. As with the $\mathrm{Tb}^{3+} / \mathrm{DPA}$ microwell assay, the SARS $_{\text {aro }}$ peptide induced leakage of ANTS from LUVs to a greater degree than its scrambled counterpart, $\mathrm{SARS}_{\mathrm{scr}}$. On average, the percent leakage detected at all $\mathrm{P} / \mathrm{L}$ ratios was approximately 2 times greater for the $\mathrm{SARS}_{\text {aro }}$ peptide as compared to the $\mathrm{SARS}_{\mathrm{scr}}$ peptide (part A versus part B of Figure 5). The degree of leakage induced by $\mathrm{SARS}_{\text {aro }}$ varied based on the lipid composition of the LUVs tested. The percent leakage detected from LUVs composed of either POPC/PI or POPC/POPG was 34 and $36 \%$, respectively, as compared to $29 \%$ leakage observed in POPC LUVs at $\mathrm{P} / \mathrm{L}$

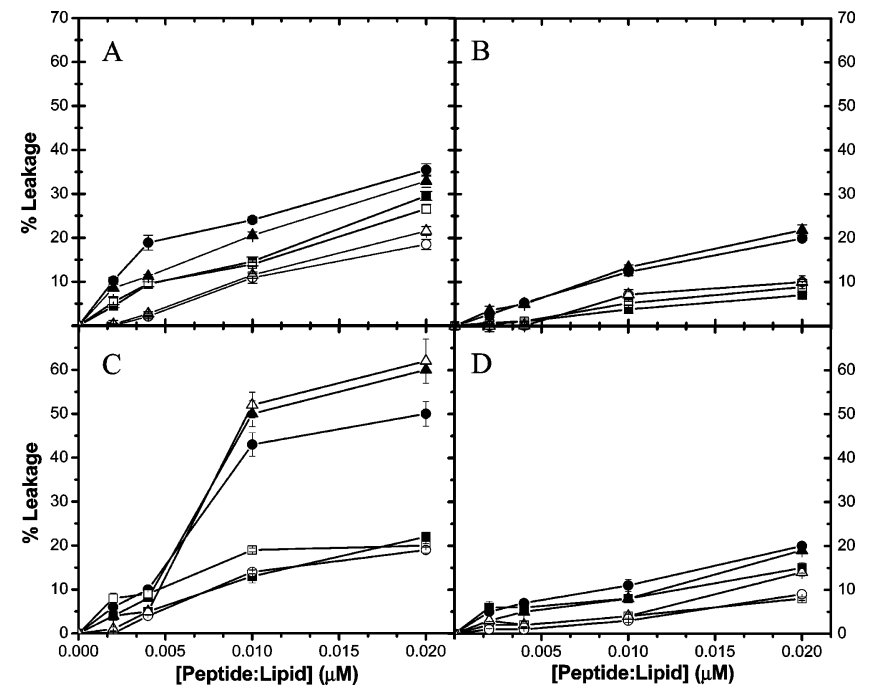

FIGURE 5: Extent of leakage from ANTS/DPX LUVs induced by the $\mathrm{CoV}$ aromatic peptides. (A) $\mathrm{SARS}_{\mathrm{aro}}$, (B) $\mathrm{SARS}_{\mathrm{scr}}$, (C) $\mathrm{MHV}_{\mathrm{aro}}$, or (D) OC43 aro peptides were added to $500 \mu \mathrm{M}$ LUVs composed

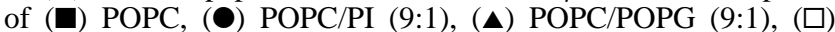
POPC/CHOL (7.5:2.5), (О) POPC/PI/CHOL (6.5:1:2.5), or $(\triangle)$ POPC/POPG/CHOL (6.5:1:2.5) at P/L molar ratios of 1:500, 1:250, $1: 100$, or $1: 50$. Samples were incubated at room temperature for $24 \mathrm{~h}$ before measuring the extent of leakage fluorometrically. Percent leakage was calculated using eq 3 ( $n=3$ per group).

ratios of 1:50 (Figure 5A). In addition, the presence of $\mathrm{CHOL}$ reduced the amount of leakage induced by the $\mathrm{SARS}_{\text {aro }}$ peptide. As compared to the $\mathrm{SARS}_{\text {aro }}$ peptide, $\mathrm{MHV}_{\text {aro }}$ induced equal or greater leakage of ANTS from LUVs, and the extent of leakage also appeared to be dependent upon the lipid composition of the vesicles. For example, at P/L ratios of 1:50, the percent leakage detected in LUVs composed of either POPC/PI or POPC/POPG was 50 and $60 \%$, respectively, as compared to $20 \%$ leakage observed in LUVs composed solely of POPC (Figure 5C). Leakage in the presence of $\mathrm{CHOL}$ was reduced for all peptides but generally not to the extent predicted by the much lower partitioning (Table 2), indicating that the membrane-permeabilizing activity per bound peptide was equal or higher in the presence of cholesterol.

The activity of OC43 3 aro in the ANTS/DPX leakage assay was considerably less in this assay than for the other two $\mathrm{CoV}$ aromatic peptides (Figure 5D). At P/L ratios of 1:50, OC43 3 aro induced minimal ANTS leakage in vesicles without cholesterol $(\sim 15-20 \%)$ and reduced leakage in vesicles containing cholesterol $(\sim 5-15 \%)$. This is in contrast to the observation, discussed above, that OC43 aro caused leakage when assayed by the $\mathrm{Tb}^{3+} / \mathrm{DPA}$ system. Although there is only a single amino acid difference between $\mathrm{MHV}_{\text {aro }}$ and 

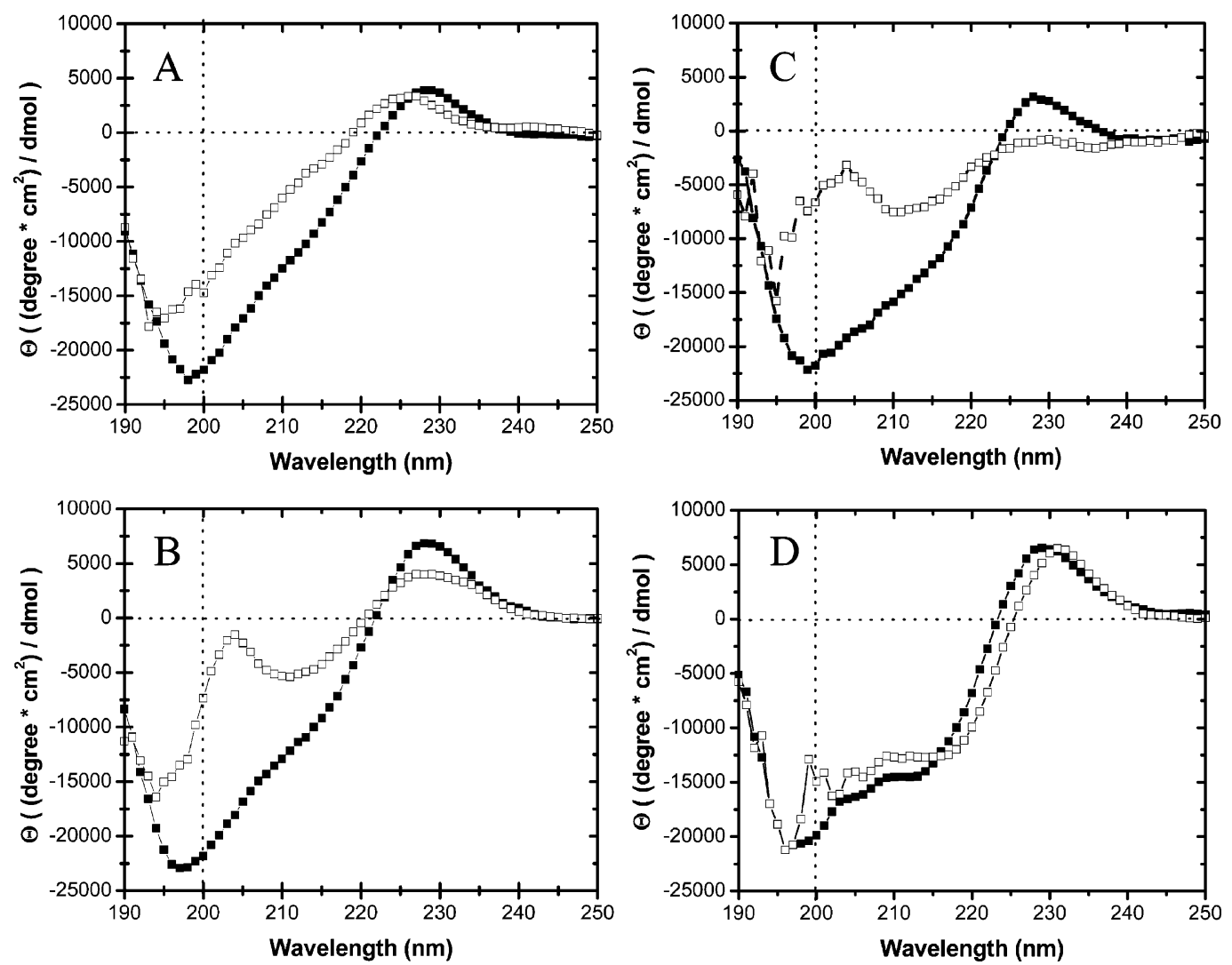

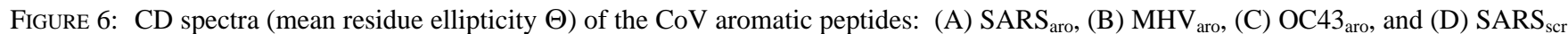
in $10 \mathrm{mM}$ potassium phosphate buffer at $\mathrm{pH} 7.0$ alone $(\mathbf{\square})$ or with $1 \mathrm{mM}$ LUVs $(\square)$ composed of POPC/PI (9:1) at room temperature (P/L ratio of 1:20).

OC43 3 aro, the pore formed by OC43 aro peptide is apparently not the same. Nonetheless, by demonstrating OC $43_{\text {aro }^{-}}$ induced leakage in at least one system, our data support the conclusion that $\mathrm{OC}_{4} 3_{\text {aro, }}$ like the other aromatic domain peptides, binds and destabilizes lipid bilayer membranes.

CD Analysis of the CoV Aromatic Peptides. To examine the potential for the formation of secondary structure upon interaction with lipid membranes, the $\mathrm{CoV}$ aromatic peptides were examined by $\mathrm{CD}$ spectroscopy. Parts $\mathrm{A}-\mathrm{C}$ of Figure 6 show representative far-UV CD spectra of the CoV aromatic peptides in buffer and with LUVs, and Figure 6D shows the results for the $\mathrm{SARS}_{\mathrm{scr}}$ peptide. In $10 \mathrm{mM}$ potassium phosphate buffer at $\mathrm{pH} 7.0$, peptides showed a random coil spectrum with single minima at $200 \mathrm{~nm}$. We next analyzed the potential of the $\mathrm{CoV}$ aromatic peptides to adopt a secondary structure in the presence of lipids by adding LUVs composed of POPC/PI at lipid concentrations of $1 \mathrm{mM}$. The $\mathrm{SARS}_{\text {aro }}$ peptide showed very little change in the CD spectrum, despite the fact that at least $60 \%$ of the peptide is bound to the vesicles under these conditions (Table 2). Similarly, for the $\mathrm{MHV}_{\text {aro }}$ and OC43 aro peptides, there was only a small change in the observed CD spectra as compared to the buffer alone (parts $\mathrm{B}$ and $\mathrm{C}$ of Figure 6). Although not indicative of a predominant, well-defined secondary structure, which would have distinct minima at 208 and $222 \mathrm{~nm}$ if $\alpha$ helical or at $\sim 218 \mathrm{~nm}$ if $\beta$ sheet, it appears that the peptides may be assuming a partially ordered structure. Nonetheless, the lack of a distinct maximum in the CD spectra at $\sim 200 \mathrm{~nm}$ demonstrates that these peptides are predominantly random coil in membranes. The same is true for the $\mathrm{SARS}_{\text {scr }}$ peptide, in Figure 6D. The small amount of secondary structure apparent in the buffer spectrum does not increase when vesicles are added, despite the fact that the $\mathrm{SARS}_{\mathrm{scr}}$ peptide binds well to these vesicles.

\section{DISCUSSION}

The recent emergence of the $\mathrm{SARS}-\mathrm{CoV}$, which induces a severe respiratory illness with a mortality rate approaching $10 \%$, has inspired increased interest in all aspects of $\mathrm{CoV}$ pathobiology. A detailed understanding of mechanisms by which $\mathrm{CoV} S$ proteins mediate fusion between the virion envelope and cellular membrane could contribute to the design of antiviral drugs and vaccines. Prior studies suggested that $\mathrm{CoV} S$ proteins might represent a unique class of viral fusion proteins. More recent analyses, however, indicate that the $\mathrm{CoV} \mathrm{S}$ proteins share structural features with class I fusion proteins (12), including a pair of extended $\alpha$ helices and a cysteine-linked "hinge" region between the helices (21, 23). In addition to these studies, our results demonstrate structural and functional similarities between the aromatic domain of the SARS-CoV S protein and that of other class I viral fusion proteins. Similar to Influenza virus, HIV, and EboV, these conserved structural motifs within the SARSCoV S protein presumably play an important role in SARS $\mathrm{CoV}$ infection, entry, and pathogenesis.

The 13-residue CoV aromatic peptides studied were selected using WW interfacial hydrophobicity plots presented in Figure 2. As compared to HIV and EboV, the SARSCoV S2 subunit exhibits common domains with high propensities to partition into lipid membranes, of which the aromatic domain scores highest for all three viruses. When determining the amino acid sequence of the SARS-CoV TM domain, Rota et al. described the aromatic domain as 
part of the TM anchor (6). In Figure 1, we depict the aromatic domain as separate from the TM anchor based on WW interfacial and octanol hydrophobicity plots of the C-terminal end of the SARS-CoV S2 subunit (Figure 2A). The separate and distinct peak $(6.63 \mathrm{kcal} / \mathrm{mol})$ generated with the WW octanol hydrophobicity scale, with a core region corresponding to amino acids $1200-1217$, strongly suggests a TM helix adjacent to the aromatic domain. Moreover, 18 amino acids are sufficient to constitute a TM anchor as shown in Figure $1(54,74)$, while the 30 amino acid length of the putative TM anchor and the aromatic domain together is considerably longer than known single-span TM helices. Therefore, on the basis of the relative hydrophobicities (interfacial versus octanol) of these two adjacent domains and the total length of the C-terminal hydrophobic domain, the SARS-CoV aromatic domain most likely constitutes a separate domain similar to that of HIV and $\operatorname{EboV}(10,55,56)$.

The aromatic domains studied represent a common motif present in some but not all class I viral fusion proteins, which is adjacent to or contiguous with the TM anchor domain. Peptides corresponding to the aromatic domains of HIV gp41 and EboV GP2 can interact with bilayer membranes and have the propensity to disrupt them $(10,75)$. Mutational studies have demonstrated that viral infectivity is sensitive to the sequence and composition of this aromatic domain $(75,76)$, suggesting that the aromatic domain is an important part of the virion/cell fusion machinery. In the work presented here, we provide data to support the hypothesis that, similar to $\mathrm{HIV}$ and $\mathrm{EboV}$, the aromatic sequence of the CoV S protein also interacts intimately with lipid membranes, induces membrane disruption, and may likewise participate in viral infectivity. Peptide-binding assays demonstrated strong partitioning into lipid membranes composed of the zwitterionic lipid POPC. Despite their modest net charges of either 0 (MHV and OC43) or +1 (SARS), the presence of anionic lipids (i.e., PI or POPG) increased binding significantly. The presence of CHOL, as observed for other viral peptides (55), reduced but did not eliminate peptide binding.

The SARS, MHV, and OC43 aromatic peptides also induced measurable lipid vesicle permeabilization in the $\mathrm{Tb}^{3+} / \mathrm{DPA}$ microwell assay and varying levels of leakage in the ANTS/DPX assay, whereas a scrambled SARS aromatic peptide $\left(\mathrm{SARS}_{\mathrm{scr}}\right)$ induced reduced leakage in both assays. It is not surprising that the SARS $_{\text {scr }}$ aromatic peptide interacted with membranes and induced some degree of leakage, given its high interfacial hydrophobicity. In fact, peptides rich in aromatic amino acids commonly partition into membranes as a result of their intrinsic hydrophobicity (52). Nonetheless, the results obtained with the SARS scr $_{\text {sin }}$ aromatic peptide suggest that the specific sequence may influence the functionality of these peptides in membranes. These structural/biophysical studies are consistent with an important role for this aromatic domain sequence in $\mathrm{CoV}$ mediated fusion and further verify that the CoV S2 protein is a class I fusion protein.

Lipid vesicles containing cholesterol, a major component of mammalian membranes in vivo, were used throughout the studies described above. Although the addition of cholesterol reduced peptide-mediated leakage, as compared to cholesterol-free vesicles, measurable leakage in the presence of cholesterol was still observed, indicating that the membrane-permeabilizing activity per peptide bound is very high in the presence of cholesterol. Several studies have examined the effect of cholesterol incorporation in lipid vesicles on peptide-mediated leakage of vesicle contents. Although some studies report that inclusion of cholesterol in membranes reduces leakage $(55,77)$, other studies report increased activity (78). The latter is observed when cholesterol is included along with other lipid molecules, especially sphingomyelin. It has been proposed that the addition of these two molecules to artificial lipid membranes may mimic the formation of segregated membrane phases or lipid "rafts" (79-81). Lipid rafts are highly ordered membrane structures believed to play a role in receptor-mediated cell signaling and viral entry. Although cholesterol is an important component of mammalian membranes, it remains to be determined how to adequately mimic the complex lipid and protein composition of biological membranes in vitro. Studies are currently being conducted to investigate the effect of sphingomyelin and cholesterol incorporation to the lipid vesicle model system described herein.

We also used CD spectroscopy to show that the coronavirus aromatic peptides that we studied were not highly structured in the presence of membranes, even under conditions where the peptides induce significant membrane destabilization and leakage. Thus, $\alpha$-helical secondary structure is neither necessary for binding nor necessary for membrane permeabilization by these aromatic domains. Studies of longer viral aromatic sequences, including peptides that contain portions of the amphipathic C helix (HR2), report $\alpha$-helical secondary structure when the peptides are membranebound $(10,56,58)$. However, secondary structure is a strongly driven thermodynamic consequence of membrane partitioning for long hydrophobic peptides (54); therefore, the biological relevance of observed secondary structure for peptides containing the aromatic domain/C helix is not clear. It is also not clear what secondary structure these aromatic sequences adopt as part of the viral fusion proteins. Importantly, the pattern of hydrophobic/hydrophilic amino acids in the membrane proximal aromatic domains of class I viral fusion proteins is not consistent with the formation of amphipathic $\alpha$ helices, a motif commonly found in membraneinteracting helices. Instead, the aromatic residues in these aromatic domains appear to have a preference for an alternating or dyad repeat pattern (53), which is consistent with a extended conformation in the interfacially bound state. Our data for the $\mathrm{CoV}$ aromatic peptides are consistent with the idea that these aromatic sequences can have biologically relevant membrane activity without a significant degree of regular secondary structure.

A working model for the process of SARS CoV virion/ cell fusion can be extrapolated from this work and from work in several other RNA virus systems $(10,22,24,29,42,46$, 82 ). After the fusion protein binds to the cellular receptor, the fusion protein undergoes a series of rearrangements, including the release of the receptor-binding subunit (S1) and trimerization and extension of the $\mathrm{N}$ helices of the $\mathrm{S} 2$ subunit toward the target membrane. The next critical step in the fusion process is the insertion of the fusion peptide into the target cell membrane (83). The fusion peptide of any $\mathrm{CoV}$ has not been conclusively identified. Weiss and co-workers identified three sequences of MHV with clusters of hydrophobic amino acids that they postulated may represent the fusion peptide(s) of this model $\mathrm{CoV}$ (26). The 
Cell Membrane

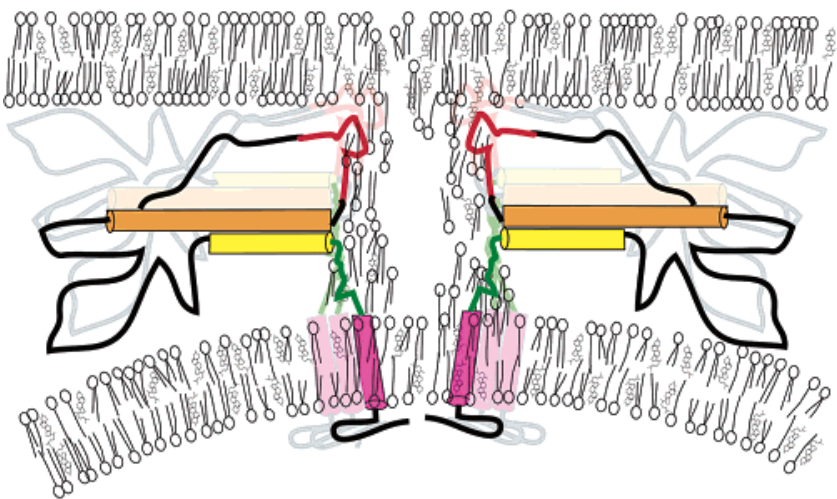

Viral Membrane

FiguRE 7: Hypothetical mechanism for the involvement of the aromatic domain in SARS CoV virion/cell fusion. Class I viral fusion proteins have a fusion peptide (red) at the amino terminus and two extended $\alpha$ helices ( $\mathrm{N}$ helix, orange; $\mathrm{C}$ helix, yellow) and most have an aromatic-rich domain (green) proximal to the TM anchor (indigo). After receptor binding with the S1 subunit, the helical domains of S2 "snap back", bringing the viral and cell membrane in closer proximity. The rearrangement of the S2 protein into the six-helix bundle confirmation results in the alignment of the fusion peptide, aromatic domain, and TM anchor, constituting a contiguous track of hydrophobic sequences that can facilitate the flow of lipid between the two membranes and the eventual fusion of the viral and host cell membranes.

WW interfacial hydrophobicity plot of the SARS CoV S2 subunit (Figure 2A) shows a region of 19 amino acids (amino acids 770-788) with a score of $3.07 \mathrm{kcal} / \mathrm{mol}$. On the basis of its similarities to the known HIV fusion peptide, we hypothesize that this region could potentially function as the SARS CoV fusion peptide.

After insertion of the fusion peptide into the target cell membrane there is a rearrangement of the fusion protein, whereby a trimer-of-hairpins is formed $(21,23)$. Subsequently, the apposing membranes are brought close enough together by the assembly of a six-helix bundle and spontaneously undergo first hemifusion and then complete fusion. The resulting structure is believed to align the fusion peptide, aromatic domain, and TM anchor (30), resulting in viral/ cell membrane fusion. On the basis of the observations that (1) the aromatic peptides of coronaviruses and other viruses $(10,55,56,58)$ strongly interact with and disrupt membranes and (2) the overall conservation of these sequences in many viruses, we hypothesize that the aromatic domain of class I viral fusion proteins plays a critical role in viral/cell membrane fusion. Specifically, we propose that the aromatic domain, in conjunction with the fusion peptide and the TM anchor, forms a continuous track of hydrophobic, membraneinteracting surfaces that provide a low-energy (low-barrier) path for lipid flow and membrane fusion during virion/cell fusion (Figure 7).

\section{REFERENCES}

1. Goldsmith, C. S., Tatti, K. M., Ksiazek, T. G., Rollin, P. E., Comer, J. A., Lee, W. W., Rota, P. A., Bankamp, B., Bellini, W. J., and Zaki, S. R. (2004) Ultrastructural characterization of SARS coronavirus, Emerging Infect. Dis. 10, 320-326.

2. Drosten, C., Gunther, S., Preiser, W., van der Werf, S., Brodt, H. R., Becker, S., Rabenau, H., Panning, M., Kolesnikova, L., Fouchier, R. A., Berger, A., Burguiere, A. M., Cinatl, J., Eickmann, M., Escriou, N., Grywna, K., Kramme, S., Manuguerra,
J. C., Muller, S., Rickerts, V., Sturmer, M., Vieth, S., Klenk, H. D., Osterhaus, A. D., Schmitz, H., and Doerr, H. W. (2003) Identification of a novel coronavirus in patients with severe acute respiratory syndrome, N. Engl. J. Med. 348, 1967-1976.

3. Marra, M. A., Jones, S. J., Astell, C. R., Holt, R. A., BrooksWilson, A., Butterfield, Y. S., Khattra, J., Asano, J. K., Barber, S. A., Chan, S. Y., Cloutier, A., Coughlin, S. M., Freeman, D., Girn, N., Griffith, O. L., Leach, S. R., Mayo, M., McDonald, H., Montgomery, S. B., Pandoh, P. K., Petrescu, A. S., Robertson, A. G., Schein, J. E., Siddiqui, A., Smailus, D. E., Stott, J. M., Yang, G. S., Plummer, F., Andonov, A., Artsob, H., Bastien, N., Bernard, K., Booth, T. F., Bowness, D., Czub, M., Drebot, M., Fernando, L., Flick, R., Garbutt, M., Gray, M., Grolla, A., Jones, S., Feldmann, H., Meyers, A., Kabani, A., Li, Y., Normand, S., Stroher, U., Tipples, G. A., Tyler, S., Vogrig, R., Ward, D., Watson, B., Brunham, R. C., Krajden, M., Petric, M., Skowronski, D. M., Upton, C., and Roper, R. L. (2003) The genome sequence of the SARS-associated coronavirus, Science 300, 1399-1404.

4. Peiris, J. S., Lai, S. T., Poon, L. L., Guan, Y., Yam, L. Y., Lim, W., Nicholls, J., Yee, W. K., Yan, W. W., Cheung, M. T., Cheng, V. C., Chan, K. H., Tsang, D. N., Yung, R. W., Ng, T. K., and Yuen, K. Y. (2003) Coronavirus as a possible cause of severe acute respiratory syndrome, Lancet 361, 1319-1325.

5. Poon, L. L., Wong, O. K., Chan, K. H., Luk, W., Yuen, K. Y., Peiris, J. S., and Guan, Y. (2003) Rapid diagnosis of a coronavirus associated with severe acute respiratory syndrome (SARS), Clin. Chem. 49, 953-955.

6. Rota, P. A., Oberste, M. S., Monroe, S. S., Nix, W. A., Campagnoli, R., Icenogle, J. P., Penaranda, S., Bankamp, B., Maher, K., Chen, M. H., Tong, S., Tamin, A., Lowe, L., Frace, M., DeRisi, J. L., Chen, Q., Wang, D., Erdman, D. D., Peret, T. C., Burns, C., Ksiazek, T. G., Rollin, P. E., Sanchez, A., Liffick, S., Holloway, B., Limor, J., McCaustland, K., Olsen-Rasmussen, M., Fouchier, R., Gunther, S., Osterhaus, A. D., Drosten, C., Pallansch, M. A., Anderson, L. J., and Bellini, W. J. (2003) Characterization of a novel coronavirus associated with severe acute respiratory syndrome, Science 300, 1394-1399.

7. Ksiazek, T. G., Erdman, D., Goldsmith, C. S., Zaki, S. R., Peret, T., Emery, S., Tong, S., Urbani, C., Comer, J. A., Lim, W., Rollin, P. E., Dowell, S. F., Ling, A. E., Humphrey, C. D., Shieh, W. J., Guarner, J., Paddock, C. D., Rota, P., Fields, B., DeRisi, J., Yang, J. Y., Cox, N., Hughes, J. M., LeDuc, J. W., Bellini, W. J., and Anderson, L. J. (2003) A novel coronavirus associated with severe acute respiratory syndrome, N. Engl. J. Med. 348, 1953-1966.

8. Siddell, S. G. (1995) The Coronaviridae; an introduction, Plenum Press, New York.

9. Carr, C. M., and Kim, P. S. (1993) A spring-loaded mechanism for the conformational change of influenza hemagglutinin, Cell $73,823-832$.

10. Suarez, T., Gallaher, W. R., Agirre, A., Goni, F. M., and Nieva, J. L. (2000) Membrane interface-interacting sequences within the ectodomain of the human immunodeficiency virus type 1 envelope glycoprotein: Putative role during viral fusion, J. Virol. 74, 80388047.

11. Wilson, I. A., Skehel, J. J., and Wiley, D. C. (1981) Structure of the haemagglutinin membrane glycoprotein of influenza virus at $3 \AA$ A resolution, Nature 289, 366-373.

12. Chambers, P., Pringle, C. R., and Easton, A. J. (1990) Heptad repeat sequences are located adjacent to hydrophobic regions in several types of virus fusion glycoproteins, J. Gen. Virol. 71, 3075-3080.

13. Gallaher, W. R., Ball, J. M., Garry, R. F., Griffin, M. C., and Montelaro, R. C. (1989) A general model for the transmembrane proteins of HIV and other retroviruses, AIDS Res. Hum. Retroviruses 5, 431-440.

14. Gallaher, W. R. (1996) Similar structural models of the transmembrane proteins of Ebola and avian sarcoma viruses, Cell 85, $477-478$

15. Heinz, F. X., and Allison, S. L. (2003) Flavivirus structure and membrane fusion, Adv. Virus Res. 59, 63-97.

16. Heinz, F. X., and Allison, S. L. (2001) The machinery for flavivirus fusion with host cell membranes, Curr. Opin. Microbiol. 4, 450455.

17. Garry, R. F., and Dash, S. (2003) Proteomics computational analyses suggest that hepatitis $\mathrm{C}$ virus E1 and pestivirus E2 envelope glycoproteins are truncated class II fusion proteins, Virology 307, 255-265. 
18. Taguchi, F. (1995) The S2 subunit of the murine coronavirus spike protein is not involved in receptor binding, J. Virol. 69, 72607263.

19. Cavanagh, D., and Davis, P. J. (1986) Coronavirus IBV: Removal of spike glycopolypeptide S1 by urea abolishes infectivity and haemagglutination but not attachment to cells, J. Gen. Virol. 67 , $1443-1448$

20. Taguchi, F., and Shimazaki, Y. K. (2000) Functional analysis of an epitope in the S2 subunit of the murine coronavirus spike protein: Involvement in fusion activity, J. Gen. Virol. 81, 28672871.

21. Bosch, B. J., van der Zee, R., de Haan, C. A., and Rottier, P. J. (2003) The coronavirus spike protein is a class I virus fusion protein: Structural and functional characterization of the fusion core complex, J. Virol. 77, 8801-8811.

22. Liu, S., Xiao, G., Chen, Y., He, Y., Niu, J., Escalante, C. R., Xiong, H., Farmar, J., Debnath, A. K., Tien, P., Jiang, S., Goldsmith, C. S., Tatti, K. M., Ksiazek, T. G., Rollin, P. E., Comer, J. A., Lee, W. W., Rota, P. A., Bankamp, B., Bellini, W. J., and Zaki, S. R. (2004) Interaction between heptad repeat 1 and 2 regions in spike protein of SARS-associated coronavirus: Implications for virus fusogenic mechanism and identification of fusion inhibitors, Lancet 363, 938-947.

23. Tripet, B., Howard, M. W., Jobling, M., Holmes, R. K., Holmes, K. V., and Hodges, R. S. (2004) Structural characterization of the SARS-coronavirus spike $\mathrm{S}$ fusion protein core, J. Biol. Chem. 279, 20836-20849.

24. Melikyan, G. B., Markosyan, R. M., Hemmati, H., Delmedico, M. K., Lambert, D. M., and Cohen, F. S. (2000) Evidence that the transition of HIV-1 gp41 into a six-helix bundle, not the bundle configuration, induces membrane fusion, J. Cell Biol. 151, 413423.

25. Russell, C. J., Jardetzky, T. S., and Lamb, R. A. (2001) Membrane fusion machines of paramyxoviruses: Capture of intermediates of fusion, EMBO J. 20, 4024-4034.

26. Luo, Z., and Weiss, S. R. (1998) Roles in cell-to-cell fusion of two conserved hydrophobic regions in the murine coronavirus spike protein, Virology 244, 483-494.

27. Luo, Z., Matthews, A. M., and Weiss, S. R. (1999) Amino acid substitutions within the leucine zipper domain of the murine coronavirus spike protein cause defects in oligomerization and the ability to induce cell-to-cell fusion, J. Virol. 73, 8152-8159.

28. Gallagher, T. M., Escarmis, C., and Buchmeier, M. J. (1991) Alteration of the $\mathrm{pH}$ dependence of coronavirus-induced cell fusion: Effect of mutations in the spike glycoprotein, J. Virol. $65,1916-1928$.

29. Skehel, J. J., and Wiley, D. C. (1998) Coiled coils in both intracellular vesicle and viral membrane fusion, Cell 95, 871874.

30. Malashkevich, V. N., Chan, D. C., Chutkowski, C. T., and Kim, P. S. (1998) Crystal structure of the simian immunodeficiency virus (SIV) gp41 core: Conserved helical interactions underlie the broad inhibitory activity of gp41 peptides, Proc. Natl. Acad. Sci. U.S.A. 95, 9134-9139.

31. Weissenhorn, W., Carfi, A., Lee, K. H., Skehel, J. J., and Wiley, D. C. (1998) Crystal structure of the Ebola virus membrane fusion subunit, GP2, from the envelope glycoprotein ectodomain, Mol. Cell 2, 605-616.

32. Weissenhorn, W., Dessen, A., Harrison, S. C., Skehel, J. J., and Wiley, D. C. (1997) Atomic structure of the ectodomain from HIV-1 gp41, Nature 387, 426-430.

33. Fass, D., Harrison, S. C., and Kim, P. S. (1996) Retrovirus envelope domain at 1.7 A resolution, Nat. Struct. Biol. 3, 465469.

34. Kobe, B., Center, R. J., Kemp, B. E., and Poumbourios, P. (1999) Crystal structure of human $\mathrm{T}$ cell leukemia virus type $1 \mathrm{gp} 21$ ectodomain crystallized as a maltose-binding protein chimera reveals structural evolution of retroviral transmembrane proteins, Proc. Natl. Acad. Sci. U.S.A. 96, 4319-4324.

35. Chan, D. C., Fass, D., Berger, J. M., and Kim, P. S. (1997) Core structure of gp41 from the HIV envelope glycoprotein, Cell 89 , 263-273.

36. Caffrey, M., Cai, M., Kaufman, J., Stahl, S. J., Wingfield, P. T., Covell, D. G., Gronenborn, A. M., and Clore, G. M. (1998) Threedimensional solution structure of the $44 \mathrm{kDa}$ ectodomain of SIV gp41, EMBO J. 17, 4572-4584.

37. Bullough, P. A., Hughson, F. M., Skehel, J. J., and Wiley, D. C. (1994) Structure of influenza haemagglutinin at the $\mathrm{pH}$ of membrane fusion, Nature 371, 37-43.
38. Joshi, S. B., Dutch, R. E., and Lamb, R. A. (1998) A core trimer of the paramyxovirus fusion protein: Parallels to influenza virus hemagglutinin and HIV-1 gp41, Virology 248, 20-34.

39. Xu, Y., Liu, Y., Lou, Z., Qin, L., Li, X., Bai, Z., Pang, H., Tien, P., Gao, G. F., and Rao, Z. (2004) Structural basis for coronavirusmediated membrane fusion. Crystal structure of mouse hepatitis virus spike protein fusion core, J. Biol. Chem. 279, 30514-30522.

40. Xu, Y., Lou, Z., Liu, Y., Pang, H., Tien, P., Gao, G. F., Rao, Z Zhu, J., Xiao, G., Yuan, F., Zheng, C., Yan, H., Cole, D. K., Bell, J. I., Qin, L., Li, X., and Bai, Z. (2004) Crystal structure of SARS-CoV spike protein fusion core, J. Biol. Chem. 279, 1.

41. Chernomordik, L. V., Frolov, V. A., Leikina, E., Bronk, P., and Zimmerberg, J. (1998) The pathway of membrane fusion catalyzed by influenza hemagglutinin: Restriction of lipids, hemifusion, and lipidic fusion pore formation, J. Cell Biol. 140, 1369-1382.

42. Danieli, T., Pelletier, S. L., Henis, Y. I., and White, J. M. (1996) Membrane fusion mediated by the influenza virus hemagglutinin requires the concerted action of at least three hemagglutinin trimers, J. Cell Biol. 133, 559-569.

43. Kanaseki, T., Kawasaki, K., Murata, M., Ikeuchi, Y., and Ohnishi, S. (1997) Structural features of membrane fusion between influenza virus and liposome as revealed by quick-freezing electron microscopy, J. Cell Biol. 137, 1041-1056.

44. Markosyan, R. M., Cohen, F. S., and Melikyan, G. B. (2003) HIV-1 envelope proteins complete their folding into six-helix bundles immediately after fusion pore formation, Mol. Biol. Cell 14, 926-938.

45. Bonnafous, P., and Stegmann, T. (2000) Membrane perturbation and fusion pore formation in influenza hemagglutinin-mediated membrane fusion. A new model for fusion, J. Biol. Chem. 275, 6160-6166.

46. Bentz, J. (2000) Membrane fusion mediated by coiled coils: A hypothesis, Biophys. J. 78, 886-900.

47. Colotto, A., and Epand, R. M. (1997) Structural study of the relationship between the rate of membrane fusion and the ability of the fusion peptide of influenza virus to perturb bilayers, Biochemistry 36, 7644-7651.

48. Pereira, F. B., Valpuesta, J. M., Basanez, G., Goni, F. M., and Nieva, J. L. (1999) Interbilayer lipid mixing induced by the human immunodeficiency virus type-1 fusion peptide on large unilamellar vesicles: The nature of the nonlamellar intermediates, Chem. Phys. Lipids 103, 11-20.

49. Pereira, F. B., Goni, F. M., Muga, A., and Nieva, J. L. (1997) Permeabilization and fusion of uncharged lipid vesicles induced by the HIV-1 fusion peptide adopting an extended conformation: Dose and sequence effects, Biophys. J. 73, 1977-1986.

50. Ruiz-Arguello, M. B., Goni, F. M., Pereira, F. B., and Nieva, J. L. (1998) Phosphatidylinositol-dependent membrane fusion induced by a putative fusogenic sequence of Ebola virus, J. Virol. $72,1775-1781$

51. Wimley, W. C., and White, S. H. (1996) Experimentally determined hydrophobicity scale for proteins at membrane interfaces, Nat. Struct. Biol. 3, 842-848.

52. Yau, W. M., Wimley, W. C., Gawrisch, K., and White, S. H. (1998) The preference of tryptophan for membrane interfaces, Biochemistry 37, 14713-14718.

53. Wimley, W. C. (2003) The versatile $\beta$-barrel membrane protein, Curr. Opin. Struct. Biol. 13, 404-411.

54. White, S. H., and Wimley, W. C. (1999) Membrane protein folding and stability: Physical principles, Annu. Rev. Biophys. Biomol. Struct. 28, 319-365

55. Saez-Cirion, A., Gomara, M. J., Agirre, A., and Nieva, J. L. (2003) Pre-transmembrane sequence of Ebola glycoprotein. Interfacial hydrophobicity distribution and interaction with membranes, FEBS Lett. 533, 47-53.

56. Suarez, T., Nir, S., Goni, F. M., Saez-Cirion, A., and Nieva, J. L. (2000) The pre-transmembrane region of the human immunodeficiency virus type-1 glycoprotein: A novel fusogenic sequence, FEBS Lett. 477, 145-149.

57. Bentz, J., Ellens, H., and Alford, D. (1990) An architecture for the fusion site of influenza hemagglutinin, FEBS Lett. 276, 1-5.

58. Shnaper, S., Sackett, K., Gallo, S. A., Blumenthal, R., and Shai, Y. (2004) The C- and the N-terminal regions of glycoprotein 41 ectodomain fuse membranes enriched and not enriched with cholesterol, respectively, J. Biol. Chem. 279, 18526-18534.

59. Watanabe, S., Takada, A., Watanabe, T., Ito, H., Kida, H., and Kawaoka, Y. (2000) Functional importance of the coiled-coil of the Ebola virus glycoprotein, J. Virol. 74, 10194-10201. 
60. Lamb, R. A., Joshi, S. B., and Dutch, R. E. (1999) The paramyxovirus fusion protein forms an extremely stable core trimer: Structural parallels to influenza virus haemagglutinin and HIV-1 gp41, Mol. Membr. Biol. 16, 11-19.

61. Lambert, D. M., Barney, S., Lambert, A. L., Guthrie, K., Medinas, R., Davis, D. E., Bucy, T., Erickson, J., Merutka, G., and Petteway, S. R., Jr. (1996) Peptides from conserved regions of paramyxovirus fusion (F) proteins are potent inhibitors of viral fusion, Proc. Natl. Acad. Sci. U.S.A. 93, 2186-2191.

62. Qureshi, N. M., Coy, D. H., Garry, R. F., and Henderson, L. A. (1990) Characterization of a putative cellular receptor for HIV-1 transmembrane glycoprotein using synthetic peptides, AIDS 4, 553-558.

63. Nieva, J. L., and Agirre, A. (2003) Are fusion peptides a good model to study viral cell fusion? Biochim. Biophys. Acta 1614 104-115.

64. Young, J. K., Li, D., Abramowitz, M. C., and Morrison, T. G. (1999) Interaction of peptides with sequences from the Newcastle disease virus fusion protein heptad repeat regions, J. Virol. 73, 5945-5956.

65. Mayer, L. D., Hope, M. J., and Cullis, P. R. (1986) Vesicles of variable sizes produced by a rapid extrusion procedure, Biochim. Biophys. Acta 858, 161-168.

66. Nayar, R., Hope, M. J., and Cullis, P. R. (1989) Generation of large unilamellar vesicles from long-chain saturated phosphatidylcholines by extrusion technique, Biochim. Biophys. Acta 986 , 200-206.

67. Rausch, J. M., and Wimley, W. C. (2001) A high-throughput screen for identifying transmembrane pore-forming peptides, Anal. Biochem. 293, 258-263.

68. Ellens, H., Bentz, J., and Szoka, F. C. (1984) pH-induced destabilization of phosphatidylethanolamine-containing liposomes: Role of bilayer contact, Biochemistry 23, 1532-1538

69. Chen, P. S., Toribara, T. Y., and Warner, H. (1956) Microdetermination of phosphorus, Anal. Chem. 28, 1756-1758.

70. Fiske, C. H., and Subbarow, Y. (1925) The colometric determination of phosphorus, J. Biol. Chem. 66, 375-400.

71. White, S. H., Wimley, W. C., Ladokhin, A. S., and Hristova, K. (1998) Protein folding in membranes: Determining energetics of peptide-bilayer interactions, Methods Enzymol. 295, 62-87.

72. Hoffman, K., and Stoffel, W. (1993) TMbase-A database of membrane-spanning segments, Biol. Chem. Hoppe-Seyler 374, 166-170.
73. Jayasinghe, S., Hristova, K., and White, S. H. (2001) Energetics, stability, and prediction of transmembrane helices, J. Mol. Biol. $312,927-934$.

74. White, S. H. (2003) Translocons, thermodynamics, and the folding of membrane proteins, FEBS Lett. 555, 116-121.

75. Munoz-Barroso, I., Salzwedel, K., Hunter, E., and Blumenthal, R. (1999) Role of the membrane-proximal domain in the initial stages of human immunodeficiency virus type 1 envelope glycoprotein-mediated membrane fusion, J. Virol. 73, 6089-6092.

76. Salzwedel, K., West, J. T., and Hunter, E. (1999) A conserved tryptophan-rich motif in the membrane-proximal region of the human immunodeficiency virus type 1 gp41 ectodomain is important for Env-mediated fusion and virus infectivity, J. Virol. 73, 2469-2480.

77. Nicol, F., Nir, S., and Szoka, F. C., Jr. (1996) Effect of cholesterol and charge on pore formation in bilayer vesicles by a $\mathrm{pH}$-sensitive peptide, Biophys. J. 71, 3288-3301.

78. Saez-Cirion, A., Nir, S., Lorizate, M., Agirre, A., Cruz, A., PerezGil, J., and Nieva, J. L. (2002) Sphingomyelin and cholesterol promote HIV-1 gp41 pretransmembrane sequence surface aggregation and membrane restructuring, J. Biol. Chem. 277, 2177621785 .

79. Ahmed, S. N., Brown, D. A., and London, E. (1997) On the origin of sphingolipid/cholesterol-rich detergent-insoluble cell membranes: Physiological concentrations of cholesterol and sphingolipid induce formation of a detergent-insoluble, liquid-ordered lipid phase in model membranes, Biochemistry 36, 10944-10953.

80. Brown, D. A., and London, E. (2000) Structure and function of sphingolipid- and cholesterol-rich membrane rafts, J. Biol. Chem. 275, $17221-17224$.

81. Silvius, J. R., del Giudice, D., and Lafleur, M. (1996) Cholesterol at different bilayer concentrations can promote or antagonize lateral segregation of phospholipids of differing acyl chain length, Biochemistry 35, 15198-15208.

82. Jardetzky, T. S., and Lamb, R. A. (2004) Virology: A class act, Nature 427, 307-308.

83. Gallaher, W. R. (1987) Detection of a fusion peptide sequence in the transmembrane protein of human immunodeficiency virus, Cell $50,327-328$.

$\mathrm{BI048515G}$ 